former has reciprocated with a large volume of chips for the pulp industry. In a very few cases the two industries have been integrated.

While Ontario does not have any major formula in the field of multi-product extraction, it has a flexible licensing system that does permit integration of operations. The systems noted may have some deficiencies that result in difficulties for one party, or both. Regardless of the difficulties, I believe the public sector is going to, and must, demand an increase in integrated operations.

This can be best achieved if the private sector realizes that the public sector is serious about this matter. Problems arising from the extraction of two products from the same licence area are, I suggest, best resolved in the private sector. As an example, an equitable charge for the use of roads and sale of residual products is preferable to an imposed arbitrary price. Would not a private sector approach to the resolution of price disputes be preferable to some other alternative?

Forest operating companies were proposed in 1947 to achieve integration. The pressure for achieving this aim is much more widespread now than then. To the extent that private industry is able to demonstrate its willingness and ability to achieve this aim, I would question the need for creating the type of public company recommended.

I would hope these comments might lead to further views on this subject on the part of readers or members who are able to speak from other vantage points.

\title{
Shelterwood Felling in
}

\section{Late Successional Stands}

\section{in Alberta's Rocky Mountain Subalpine Forest}

\author{
By R. J. DAY \\ Faculty of Forestry \\ University of Toronto \\ Formerly \\ Department of Forestry and Rural Development \\ Calgary, Alberto \\ ODC 221.02
}

"The success of uniform shelterwood felling for the reproduction of spruce and fir results from the provision of abundant seed and adequate environments for germination and growth that are not subject to excessive heating and drying of the seedbed."

\section{Abstract}

The silviculture of the spruce-pine phase of the Alberta subalpine forest is discussed in relation to ecological problems and previous work.

A trial of uniform shelterwood felling combined with seedbed preparation is described and followed to the third year.

The abundant regeneration confirms the importance of shelter for spruce reproduction and suggests that practical methods be advised to provide it.

Progressive strip cutting with scarification is suggested.

La coupe progressive en Alberta dans les peuplements quasi-climatiques de la forêt subalpine des rocheuses.

\section{Résumé}

La pratique sylvicole dans des peuplements rendus au stade épinette-pin de la forêt subalpine de l'Alberta est distuée en tenant compte des problèmes écologiques et des travaux antérieurs.
Un essai de coupes progressives combinées à une préparation du site a été suivi durant trois ans.

L'abondance de la régénération confirme l'importance du couvert pour l'établissement de l'épinette et incite à rechercher des méthodes pratiques de s'en pourvoir.

Des coupes progressives par bandes combinées à la scarification sont proposées.

\section{Introduction}

The main source of timber on the eastern slope of the Southern Alberta Rockies has been the late successional lodgepole pine - hybrid spruce stands that followed fires 150 to 250 years ago (Day 1965). A pattern of successive periods of domination by lodgepole pine (Pinus contorta Dougl. var. latifolia Engelm.), hybrid spruce (Picea glauca (Moench) Voss. X. P. engelmannii Parry) and alpine fir (Abies lasiocarpa (Hook.) Nutt.) has characterized the changing structure of these stands after disturbance by fire (Horton 1956). The regular and uniform pioneer pine canopy is maintained by ingrowth from a spruce understory for periods exceeding 200 years. Eventually the sporadic death of the aging pine and weaker spruce dominants gradually release fir and spruce advanced reproduction and induce an irregular canopy structure. Ecologically, the succession progresses from even-aged pine, through broadly-aged pine-spruce to irregularly-aged spruce-fir or fir-spruce. The rate at which the succession progresses depends on the fertility of the environment. The extent to which the succession progresses depends on time limits set by fire 
probability (Day 1965). The high-volume phases of this succession have been logged because of their economic value. In this successional system, biomass culminates in the pine-spruce phase where average volumes of 30 to $40 \mathrm{M} \mathrm{bd}$. ft. per acre occur on fertile sites. As the canopy of the pine-spruce phase breaks up, fir, spruce and whitebark pine are released and establish themselves in an irregular manner. The break up of the pine-spruce canopy is the cause of a rapid decline in biomass which is unsatisfactory from the economic standpoint because volumes drop to 15 to $20 \mathrm{M}$ bd. ft. per acre 300 or more years after fire. This has led some to suggest that fire is essential to the maintenance of productivity in these stands (Bloomberg 1950). The problem is really one of change in stand composition and structure, which can be better corrected by management than by uncontrolled fire.

The silvicultural possibilities for the regeneration of spruce and pine in the spruce-pine phase ${ }^{1}$ have been considered by many workers. L. A. DeGrace (1950) discussed the feasibility of selective logging, but it was never implemented because of uniform canopy structure and problems of high cost and windthrow. Quaite $(1950)^{2}$ tested the uniform shelterwood method and operational trials of various forms of partial cutting were attempted, but were discontinued because of windthrow and lack of evidence of satisfactory regeneration. Other measures such as clear cutting or clear cutting with scarification in blocks of various sizes were more attractive because of lower felling costs and the promise of satisfactory regeneration (Crossley 1952, 1955 a and b). Subsequent studies of the problem of obtaining regeneration after clear cutting in the region have shown that stocking is unreliable and usually inadequate (Day and Duffy 1961). Soil drought, lethal temperatures at the soil surface and atmospheric drought aggravate the problem (Day 1963 a and b). On the basis of study of natural regeneration on clear cuttings, shelter is needed to provide satisfactory microenvironmental conditions for early establishment.

\section{Objective}

The objective of this study was to test the effectiveness of a carefully planned uniform shelterwood felling in the pine-spruce phase, primarily for spruce regeneration.

\section{Methods}

\section{The Stand and Cutting Method}

In 1963, two 5 -acre blocks ( $5 \times 10$ chains) were established in a mature stand ( 235 years from fire) in the Crowsnest Forest, which lies in the southern Alberta Rockies (Figure 1).

\footnotetext{
${ }^{1}$ Usually referred to as the spruce-fir phase in other literature because it contains the "climax" species. True spruce-fir is a rarity in southern Alberta because of a high pine component related to fire frequency.

2 Other unpublished data by Quaite were inspected by the writer.
}

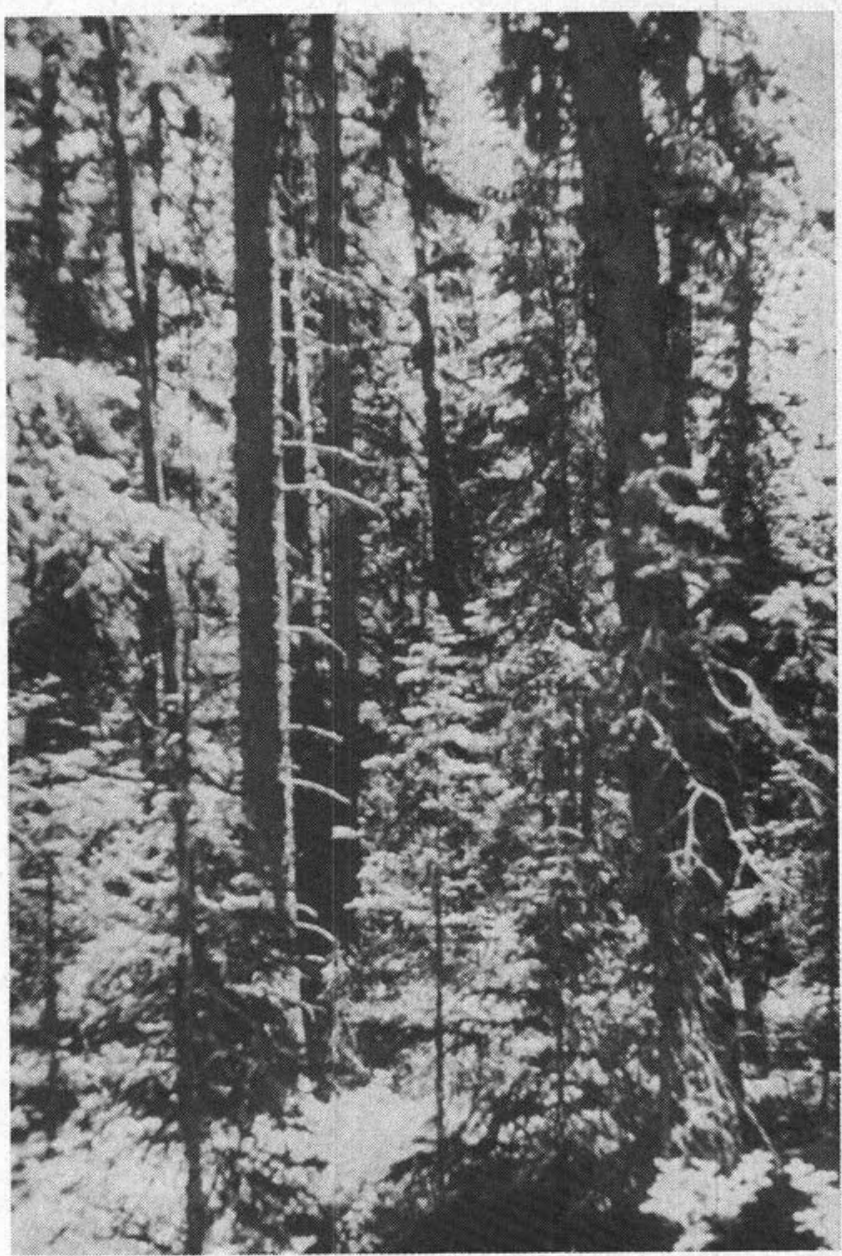

Fig. 1. Mature spruce-pine fir before uniform shelterwood felling

Both blocks are located at 5,500 feet elevation on an east-southeast moderate till slope adajacent to Goat Creek. This creek drains a subalpine mountain valley originating in a cirque near the Continental Divide two miles westward. The experimental blocks are located on the high-yield Menziesia-Tiarella site type defined by Ogilvie (1963). Block I was located five chains upslope from Block II and is on slightly steeper terrain. Limited access to the blocks would not permit any other arrangement. In 1963 , a 25 per cent inventory was made of both blocks.

The cruise showed that both blocks had a high timber volume for the region, $35 \mathrm{M} \mathrm{bd}$. ft. per acre. There was a marked difference in species composition between the blocks related to change in slope angle and drainage pattern. Block I was mainly spruce, Block II mainly pine (Table 1 ).

A 30 per cent initial shelterwood felling was prescribed after careful examination of the stand data given in Table 1 and Figure 2. This intensity of initial felling was selected to provide adequate light on the forest floor and to reduce root competition without exposing the stand to severe windthrow. When satisfactory regeneration has been obtained, a final felling will be prescribed to complete the operation. 

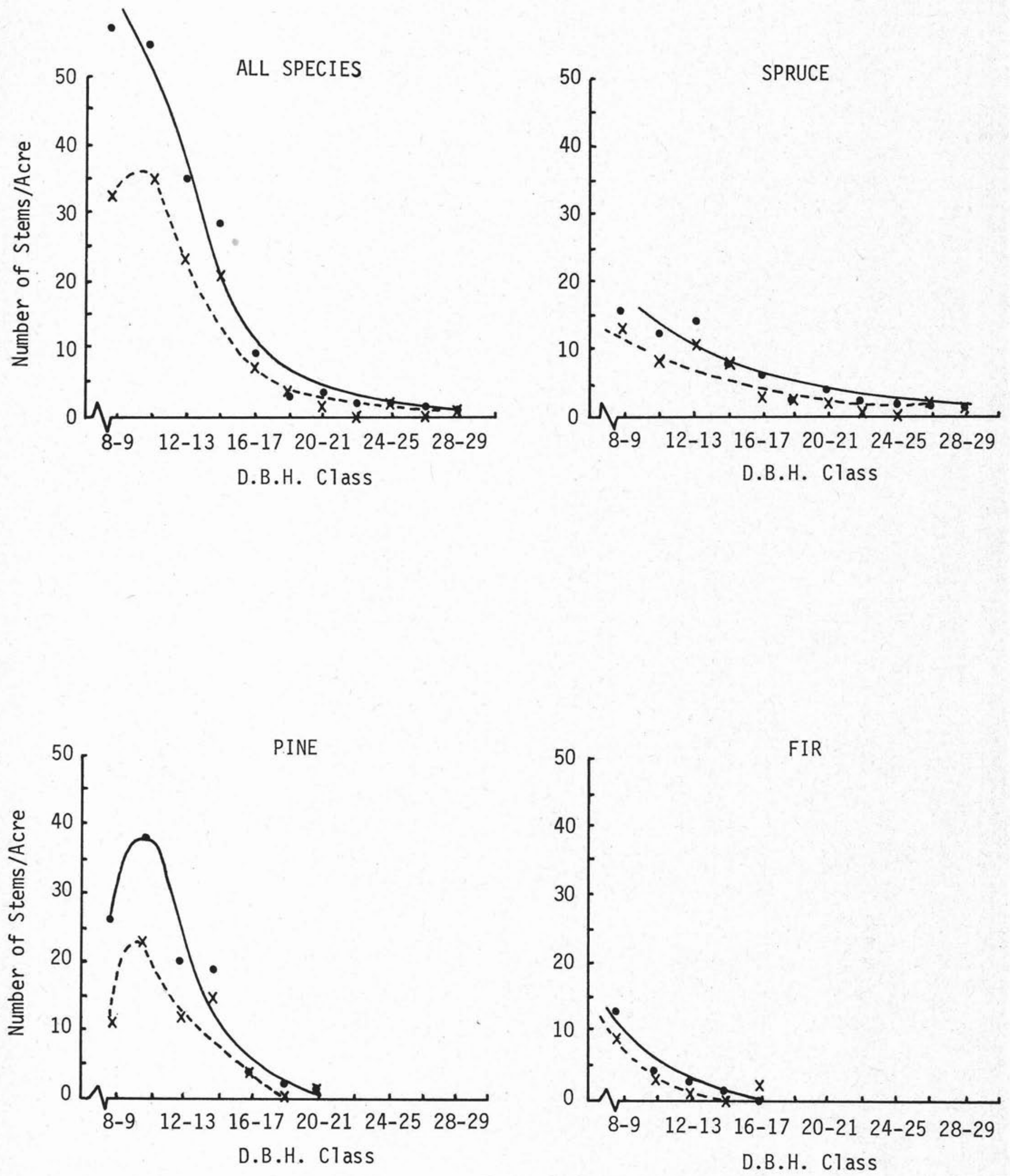

Figure 2. Diameter Class Distribution Curves 
Table 1 Cruise volumes per acre and volumes per acre marked for shelterwood felling by species for Blocks I and II in 1963 (in $\mathrm{m}$. fbm for trees over $8^{\prime \prime} \mathrm{dbh}$ )

\begin{tabular}{|c|c|c|c|c|c|c|c|c|c|}
\hline \multirow{2}{*}{ Volumes Cruised and Marked } & \multicolumn{4}{|c|}{ Block I } & \multicolumn{4}{|c|}{ Block II } & \multirow{2}{*}{$\begin{array}{l}\text { Mean } \\
\text { Mean }\end{array}$} \\
\hline & Spruce & Pine & Fir & $\begin{array}{l}\text { All } \\
\text { Spp. }\end{array}$ & Spruce & Pine & Fir & $\begin{array}{l}\text { All } \\
\text { Spp. }\end{array}$ & \\
\hline Estimated volume per acre $(\mathrm{m} . \mathrm{fbm}) \ldots \ldots \ldots$ & 19.9 & 13.4 & 1.9 & $\begin{array}{r}35.4 \\
\pm 2.9\end{array}$ & 10.2 & 24.4 & 0.4 & $\begin{array}{r}35.0 \\
\pm 2.1\end{array}$ & 35.2 \\
\hline $\begin{array}{l}\text { Volume per acre marked in } 1963 \text { for felling in } \\
1964(\mathrm{~m} . \mathrm{fbm}) \ldots \ldots \ldots \ldots \ldots \ldots \ldots \ldots \ldots \ldots \ldots \ldots\end{array}$ & 5.4 & 5.4 & 0.8 & 11.6 & 2.9 & 7.2 & 0.1 & 10.1 & 10.9 \\
\hline Per cent marked.... & 26.9 & 40.0 & 41.2 & 32.7 & 28.2 & 29.2 & 28.2 & 29.0 & 30.8 \\
\hline
\end{tabular}

The following rules were applied when the initial felling was marked:

1. Do not make gaps and maintain uniform spacing.

2. Remove trees likely to windthrow.

3. Remove unhealthy and misshapen trees.

4. Retain spruce over pine and pine over fir.

The volume marked was close to the objective set for the study since it represents an average of 30.8 per cent of the standing volume over 8 inches d.b.h. The effect of the marking rules was to remove a higher proportion of pine and fir. This was related to rule 4 , and was caused by the low vitality and poor crown quality of the pine and by the decadent and suppressed nature of the fir. The diameter class frequency distributions for the component species before and after felling are shown in Figure 2.

The felling and skidding were completed in August 1964 with minimal damage. Figure 3 shows the appearance of the stand after felling.

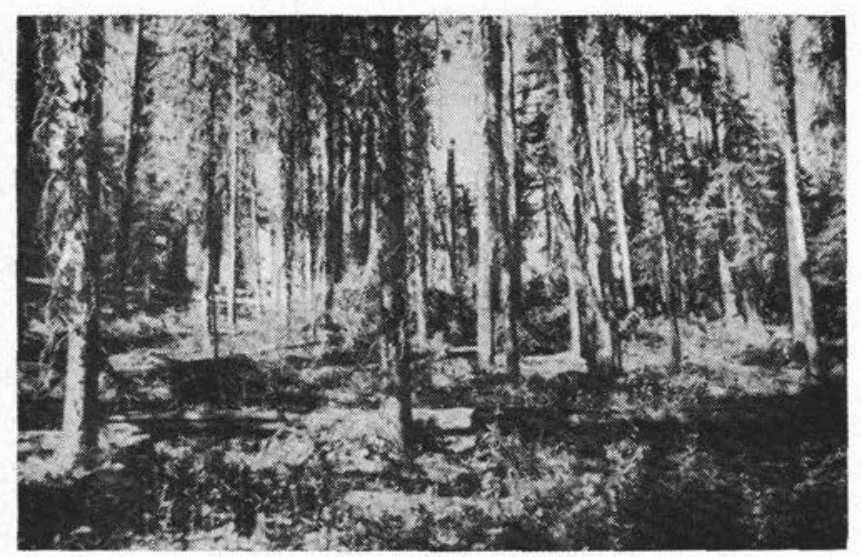

Fig. 3. After shelterwood felling in 1964.

A D-6 crawler tractor operating only on a skid road through the centre of each block yarded the logs in a herringbone pattern without damage to the residual trees.

Evaluation of Advanced Reproduction, Seedfall, Scarification and Reproduction After Shelterwood Felling.

Advanced reproduction was enumerated before logging in 1963. Ten sample lines were located at random across each block. The sample lines were composed of groups of five milliacre plots in line systematically separated by an interspace of equal length (33 feet). Stocking to advanced reproduction was recorded on all milliacre plots, numbers were recorded only on the fifth milliacre plot in each group. Five per cent of the area was enumerated for stocking, one per cent for number of seedlings per acre. The reproduction was sampled by species and height class. Three height classes were recognized $0.1-1.0$ inch, $1.1-7.0$ inches and $>7.0$ inches. These classes were selected so that ephemeral germinants $(0.1-1.0$ inches in height) could be excluded from abundance estimates, and so that the abundance of advanced reproduction over 10 years in age ( $>7.0$ inches in height) could be approximately estimated (Day 1963).

Seedfall was evaluated after felling in $40 \mathrm{y} / 4$-milliacre cardboard seedtraps ${ }^{3}$ in the fall of 1964. Ten seed traps were set up in wood frames at equal intervals in east-west transects across each half block. Spruce seed was collected in November.

Scarification was implemented immediately after logging by a crawler tractor (D-6 Caterpillar) equipped with a dozer blade. Half of each 5 -acre block was scarified. The amount of scalped and disturbed soil resulting from both the logging operation and the scarification treatment is given in Table 2.

Table 2 Percentage of land scalped or scalped and disturbed by_logging and scarification treatment in 1964

\begin{tabular}{|c|c|c|}
\hline Blocks & $\begin{array}{c}\text { Percentage } \\
\text { scalped }\end{array}$ & $\begin{array}{l}\text { Percentage } \\
\text { scalped and } \\
\text { disturbed }^{4}\end{array}$ \\
\hline $\begin{array}{ll}\text { Non-scarified } & \text { IA } \\
\text { IIB } \\
\text { Scarified } & \text { IB. } \ldots \ldots \ldots \\
& \text { IIA......... }\end{array}$ & $\begin{array}{r}8 \\
2 \\
13 \\
19\end{array}$ & $\begin{array}{r}9 \\
2 \\
25 \\
33\end{array}$ \\
\hline
\end{tabular}

In 1967, three years after shelterwood felling, the percentage stocking and numbers per acre of reproduction were re-enumerated. A similar random strip sampling technique was used with the following differences. Relocation of the original sample lines was not feasible. As separate samples had to be enumerated on scarified and non-scarified halves

\footnotetext{
${ }^{3}$ The reader should be cautioned against further use of this trap described by Easley and Chaiken 1951 because of rapid weathering and high cost. The trap was only satisfactory for the vital fall 1964 measurement in this study.

${ }^{4}$ Intermixed L. F. and $\mathrm{H}$. humus and mineral soil.
} 
of each block, the sampling intensity was doubled to 10 per cent for stocking and 2 per cent for numbers per acre of reproduction. Five randomly located lines of sample plots were tallied on each half block. Each sample line was composed of contiguous groups of ten milliacre plots in line. Stocking was recorded on all milliacre plots, numbers per acre on the fifth and tenth plots in each group of ten plots. The height of the principal seedling on each milliacre in the 1.1-7.0 inch size class was measured to indicate the performance of reproduction released and established since the 1964 felling.

\section{Analysis}

Enumeration of reproduction by random strips permitted comparison of average stocking values and variances for individual and groups of species on scarified and non-scarified blocks. Both block and scarification treatment effects were compared by the " $\mathrm{t}$ " test.

\section{Results}

The effectiveness of the experimental felling and seedbed preparation treatments can best be judged by comparison of the 1963 and 1967 enumerations. Results presented will be restricted to reproduction data. Release in the residual stand is of little importance in late stage successional forest. Windthrow was negligible.

\section{Advanced Reproduction 1963}

The abundant advanced reproduction recorded in 1963 (Table 3 ) is typical of most late successional stands in the region. Percentage stocking and numbers per acre of advanced reproduction superficially appear to be highly satisfactory. Unfortunately, Table 3 shows that much of the spruce and fir advanced reproduction is ephemeral. The exposure that follows clear cutting would eliminate most of the spruce and fir in the $0-1$ " size class. Many of the larger fir would also be eliminated by dessication and logging damage. Thus average stocking values for advanced reproduction surviving on cutover land in the Crowsnest Forest are low (Day and Duffy 1963) when compared to those measured in this study (Table 4). Logged-over land ad-
Table 4 Percentage stocking to advanced reproduction on the blocks before shelterwood felling in relation to the average stocking measured in the Crowsnest Forest after logging

\begin{tabular}{c|c|c|c|c}
\hline $\begin{array}{c}\text { Time of } \\
\text { Logging }\end{array}$ & $\begin{array}{c}\text { Hybrid } \\
\text { Spruce }\end{array}$ & $\begin{array}{c}\text { Alpine } \\
\text { Fir }\end{array}$ & $\begin{array}{c}\text { White- } \\
\text { bark } \\
\text { Pine }\end{array}$ & $\begin{array}{c}\text { All } \\
\text { Species }\end{array}$ \\
\hline $\begin{array}{c}\text { Before Logging } \\
\text { (Day 1967) .... }\end{array}$ & 42 & 84 & 8 & 89 \\
$\begin{array}{c}\text { After Logging } \\
\text { (Day \& Duffy }\end{array}$ & 21 & 6 & $1^{6}$ & 25 \\
\hline
\end{tabular}

${ }^{6}$ Lodgepole Pine

joining the northern boundary of the shelterwood blocks was no exception to this rule. As a result of poor stocking three years after logging, scarification and direct seeding were attempted with marginal success.

\section{Spruce Seedfall 1964}

Seedfall after logging in fall 1964 was very satisfactory and uniform even though the seed year was rated "poor" by local foresters. The abundance of seedfall in a poor year is caused by the shelterwood which always appears to supply adequate seed. Seedfall was estimated in numbers of sound spruce seed as follows:

\section{Block I $\quad 404,000$ per acre Block II 248,000 per acre}

\section{Reproduction 1967}

Reproduction is very abundant on both scarified and non-scarified blocks (Table 5). The shelterwood felling treatment did not markedly change the percentage stocked to advanced reproduction recorded in 1963, but the number of seedlings per acre was approximately doubled on the non-scarified blocks and quadrupled on the scarified blocks.

Reproduction data was presented (in Table 6) after elimination of the 0 to 1.0 inch seedlings which are mainly ephemeral germinants. The environment for establishment and growth is so improved by shelterwood felling that the number per acre of es-

Table 3 Percentage stocking and numbers per acre of advanced reproduction by species and size classes

\begin{tabular}{|c|c|c|c|c|c|c|c|c|c|c|c|c|c|c|}
\hline \multirow[b]{2}{*}{ Block } & \multicolumn{4}{|c|}{ Hybrid Spruce } & \multicolumn{4}{|c|}{ Alpine Fir } & \multicolumn{4}{|c|}{ White barked Pine ${ }^{6}$} & \multirow{2}{*}{$\begin{array}{c}\text { All } \\
\text { Species } \\
\text { Any Size }\end{array}$} & \multirow{2}{*}{$\begin{array}{l}\text { Basis } \\
\text { No. of } \\
\text { Milli- } \\
\text { acres }\end{array}$} \\
\hline & $0-1^{\prime \prime}$ & 1.1-7" & $>7.1^{\prime \prime}$ & Al1 & $0-1^{\prime \prime}$ & 1.1-7" & $>7.1^{\prime \prime}$ & Al1 & $0-1^{\prime \prime}$ & $1.1-7^{\prime \prime}$ & $>7.1^{\prime \prime}$ & All & & \\
\hline $\begin{array}{l}\text { I } \\
\text { II }\end{array}$ & $\begin{array}{l}30 \\
39\end{array}$ & $\begin{array}{r}14 \\
. \quad 21\end{array}$ & $\begin{array}{l}4 \\
6\end{array}$ & $\begin{array}{l}38 \\
47\end{array}$ & $\begin{array}{l}68 \\
50\end{array}$ & $\begin{array}{r}\text { (per cen } \\
60 \\
55\end{array}$ & $\begin{array}{c}\text { stocking } \\
37 \\
42\end{array}$ & $\begin{array}{l}84 \\
84\end{array}$ & $\frac{1}{2}$ & $\begin{array}{l}6 \\
9\end{array}$ & $\begin{array}{l}3 \\
2\end{array}$ & $\begin{array}{r}71 \\
11\end{array}$ & $\begin{array}{l}88 \\
90\end{array}$ & $\begin{array}{l}250 \\
250\end{array}$ \\
\hline Average & 35 & 18 & 5 & 42 & 59 & 58 & 40 & 84 & 1 & 8 & 2 & 8 & 89 & 500 \\
\hline $\begin{array}{l}\text { I } \\
\text { II }\end{array}$ & $\begin{array}{r}820 \\
1780\end{array}$ & $\begin{array}{l}260 \\
640\end{array}$ & $\begin{array}{r}20 \\
200\end{array}$ & $\begin{array}{l}1100 \\
2620\end{array}$ & $\begin{array}{l}2720 \\
1460\end{array}$ & $\begin{array}{l}\text { numbers } \\
2000 \\
1820\end{array}$ & $\begin{array}{c}\text { per acre) } \\
540 \\
1000\end{array}$ & $\mid \begin{array}{l}5260 \\
4280\end{array}$ & $\begin{array}{r}0 \\
20\end{array}$ & $\begin{array}{l}120 \\
260\end{array}$ & $\begin{array}{l}60 \\
20\end{array}$ & $\begin{array}{l}180 \\
300\end{array}$ & $\begin{array}{l}6540 \\
7200\end{array}$ & $\begin{array}{l}50 \\
50\end{array}$ \\
\hline Average & 1300 & 450 & 110 & 1860 & 2090 & 1910 & 770 & 4770 & 10 & 190 & 40 & 240 & 6870 & 100 \\
\hline
\end{tabular}

${ }^{5}$ No lodgepole pine were represented in the advanced reproduction. 
Table 5 Percentage stocking and numbers per acre of reproduction of all sizes before and after shelterwood felling

\begin{tabular}{|c|c|c|c|c|c|c|c|c|c|c|}
\hline \multirow[b]{2}{*}{ Condition and Time } & \multicolumn{2}{|c|}{$\begin{array}{l}\text { Hybrid } \\
\text { Spruce }\end{array}$} & \multicolumn{2}{|c|}{$\begin{array}{l}\text { Alpine } \\
\text { Fir }\end{array}$} & \multicolumn{2}{|c|}{$\begin{array}{l}\text { Lodgepole } \\
\text { Pine }\end{array}$} & \multicolumn{2}{|c|}{$\begin{array}{l}\text { Whitebark } \\
\text { Pine }\end{array}$} & \multicolumn{2}{|c|}{$\begin{array}{c}\text { All } \\
\text { Species }\end{array}$} \\
\hline & $\begin{array}{c}\% \\
\text { Stock }\end{array}$ & No/Ac. & $\begin{array}{c}\% \\
\text { Stock }\end{array}$ & No/Ac. & $\begin{array}{c}\% \\
\text { Stock }\end{array}$ & No/Ac. & $\begin{array}{c}\% \\
\text { Stock }\end{array}$ & No/Ac. & $\begin{array}{c}\% \\
\text { Stock }\end{array}$ & No/Ac. \\
\hline Before Felling $1963 \ldots \ldots$. & 42 & 1,860 & 84 & 4,770 & 0 & 0 & 8 & 240 & 89 & 6,870 \\
\hline $\begin{array}{c}\text { After Felling } 1967 \text { N.Sc.* } \\
\text { Sc.* }\end{array}$ & $\begin{array}{l}35 \\
59\end{array}$ & $\begin{array}{r}3,225 \\
10,750\end{array}$ & $\begin{array}{l}66 \\
84\end{array}$ & $\begin{array}{r}8,975 \\
14,975\end{array}$ & + & $\begin{array}{r}25 \\
1,325\end{array}$ & $\begin{array}{l}4 \\
5\end{array}$ & $\begin{array}{l}150 \\
450\end{array}$ & $\begin{array}{l}78 \\
89\end{array}$ & $\begin{array}{l}12,375 \\
27,500\end{array}$ \\
\hline
\end{tabular}

$*$ N.Sc. $=$ Non-Scarified; Sc. $=$ Scarified.

Table 6 Percentage stocking and numbers per acre of reproduction in the combined 1.1 to 7 and $7.1+$ size classes before and after shelterwood felling

\begin{tabular}{|c|c|c|c|c|c|c|c|c|c|c|}
\hline \multirow[b]{2}{*}{ Condition and Time } & \multicolumn{2}{|c|}{$\begin{array}{l}\text { Hybrid } \\
\text { Spruce }\end{array}$} & \multicolumn{2}{|c|}{$\begin{array}{l}\text { Alpine } \\
\text { Fir }\end{array}$} & \multicolumn{2}{|c|}{$\begin{array}{l}\text { Lodgepole } \\
\text { Pine }\end{array}$} & \multicolumn{2}{|c|}{$\begin{array}{l}\text { Whitebark } \\
\text { Pine }\end{array}$} & \multicolumn{2}{|c|}{$\begin{array}{l}\text { All } \\
\text { Species }\end{array}$} \\
\hline & $\begin{array}{c}\% \\
\text { Stock }\end{array}$ & No/Ac. & $\begin{array}{c}\% \\
\text { Stock }\end{array}$ & No/Ac. & $\begin{array}{c}\% \\
\text { Stock }\end{array}$ & No/Ac. & $\begin{array}{c}\% \\
\text { Stock }\end{array}$ & No/Ac. & $\begin{array}{c}\% \\
\text { Stock }\end{array}$ & No/Ac. \\
\hline Before Felling $1963 . . . \ldots$. & 22 & 280 & 73 & 1,340 & 0 & 0 & 8 & 115 & 77 & 1,735 \\
\hline $\begin{array}{l}\text { After Felling } 1967 \text { N.Sc.* } \\
\text { Sc.* }\end{array}$ & $\begin{array}{l}31 \\
54\end{array}$ & $\begin{array}{l}1,825 \\
7,075\end{array}$ & $\begin{array}{l}64 \\
78\end{array}$ & $\begin{array}{r}5,650 \\
11,800\end{array}$ & $+\vec{t}$ & $\begin{array}{r}0 \\
725\end{array}$ & $\begin{array}{l}3 \\
5\end{array}$ & $\begin{array}{l}150 \\
450\end{array}$ & $\begin{array}{l}73 \\
83\end{array}$ & $\begin{array}{r}7,625 \\
20,050\end{array}$ \\
\hline
\end{tabular}

${ }^{*}$ N.Sc. $=$ Non-Scarified; Sc. $=$ Scarified.

tablished seedlings has increased fourfold on the non-scarified blocks and tenfold on the scarified blocks. Though the stocking percentage to fir and whitebark pine was reduced after shelterwood felling, that of spruce and lodgepole pine increased. The abundance of spruce on the scarified blocks is now unusually high for the region, with a stocking percentage of 54 and 7,075 seedlings per acre. The treatment has increased the number of spruce sixfold on the non-scarified blocks and $\mathbf{2 5}$-fold on the scarified blocks over that measured before treatment.

The increase in stocking to spruce in response to scarification treatment was found to be highly significant, that of fir non-significant because of a high block variance.

\section{Growth of Reproduction}

The height of the dominant spruce and dominant fir seedling amongst the regeneration that occurred on each stocked quadrat was measured in August 1967, three growing seasons after seedfall. Regeneration in the 0 to 1.1 inch height class was not measured because of their ephemeral nature, nor was advanced reproduction older than three years. The average dominant heights of these seedlings (almost all were three years old) is given in Table 7 (Figure 4).

These heights appear very satisfactory for the region by comparison with the heights of three year seedlings on similar but clear cut sites which have been shown to average 1.5 inches for spruce and 1.1 inches for fir (Day 1963a). Heights measured on non-scarified blocks were 13 per cent and 25 per cent greater for fir and spruce respectively than those on the scarified blocks. This suggested that removal of the A horizon may affect fertility. This difference is not serious.

\section{Discussion and Silvicultural Proposals}

The results of this study show that the abundant advanced reproduction that occurs beneath commercial late successional pine-spruce and spruce-fir stands in the Crowsnest Forest can be retained and augmented by shelterwood felling. There is little doubt about the superiority of shelterwood when

Table 7 Average height of dominant regeneration in inches three years after shelterwood felling

\begin{tabular}{|c|c|c|c|}
\hline \multicolumn{2}{|c|}{ Treatment } & Hybrid Spruce & Alpine Fir \\
\hline \multirow[t]{2}{*}{ Scarified Blocks } & …… & $\begin{array}{l}2.13 \\
2.18\end{array}$ & $\begin{array}{l}3.02 \\
3.11\end{array}$ \\
\hline & $h \ldots \ldots \ldots$ & 2.16 & 3.07 \\
\hline \multirow[t]{2}{*}{ Non-scarified Blocks } & $\begin{array}{l}\text { IB } \ldots \ldots \ldots \\
2 \mathrm{~A} \ldots \ldots \ldots\end{array}$ & $\begin{array}{l}2.51 \\
3.25\end{array}$ & $\begin{array}{l}3.62 \\
3.33\end{array}$ \\
\hline & Both & 2.88 & 3.47 \\
\hline
\end{tabular}

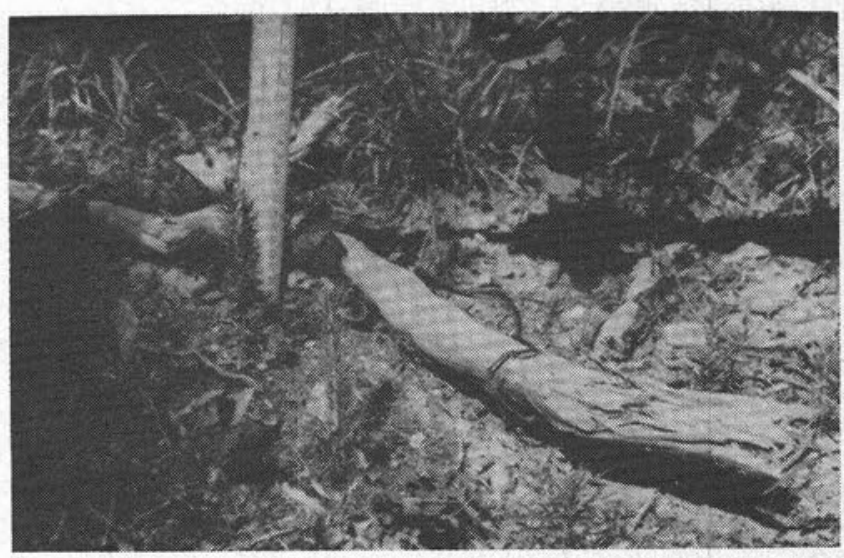

Fig. 4. Spruce and fir regeneration showing excellent leader in the third year. 
compared with previous regeneration results on adjacent clear cuts (Day and Duffy 1963). The principal cause of post-logging mortality of advanced reproduction is probably climatic exposure at a time when the reproduction lacks sun needles and adequate roots (Day $1963 \mathrm{a}$ and b). The severe desiccation of larger advanced fir reproduction after clearcutting is shown by 60 to 80 per cent needle browning and defoliation. Smaller seedlings suffer severe drought mortality.

Beneath the canopy of an uncut stand, seedfall and environments appear to be satisfactory for the production of abundant small advanced reproduction, but seedling growth is poor because of severe root competition and diffuse light. Alpine fir is a more effective competitor than hybrid spruce beneath such forest. Fir has a lower compensation point and an inherent capacity to survive high levels of root competition and so it is the only species that is well represented in the largest size class, $>7.1$ inches (Table 4). In contrast, spruce is only abundant in the 0-1 inch size class diminishing rapidly in both stocking and numbers per acre in the larger size classes. Thus it appears that although the conditions are favourable for germination of spruce and alpine fir, only alpine fir can survive the low light levels and severe root competition.

Removal of 30 per cent of the commercial basal area in a uniform shelterwood felling significantly increased both the abundance and growth of spruce and fir seedlings. The increase in numbers of seedlings was much greater on block halves that had been scarified after shelterwood felling, but height growth was slightly less than that measured on non-scarified block halves. Tables 5 and 6 show that the treatments have been highly satisfactory in producing abundant reproduction and there is little doubt that a very adequate stocking will follow the final felling. None of the reproduction methods tested for regeneration of late-successional forest in this region has proved nearly as effective as this treatment.

The success of uniform shelterwood felling for the reproduction of spruce and fir results from provision of abundant seed and adequate environments for germination and growth that are not subject to excessive heating and drying of the seedbed. In addition, removal of 30 per cent of the stand effectively reduces the amount of root competition and permits sufficient light to reach the forest floor to provide a warmer soil and near optimum light levels for photosynthesis.

The problem of uniform shelterwood felling lies in the expense of marking, felling and extracting the timber. Although the treatment is ecologically desirable, it is not likely to be implemented for economic reasons. The results of this study strongly recommend that other forms of shelterwood be tested in the region. It is suggested that progressive strip cutting could provide an economically feasible alternative to the present patch-cutting system. The progression of strips would of necessity be into the sun and prevailing wind in order to provide seed and shelter for reproduction.

\section{Acknowledgement}

May I express my gratitude to the Canadian Forestry Service for support and editorial advice, and to the Alberta Department of Lands and Forests, Blairmore for interest, enthusiasm and unstinted assistance.

\section{References}

BLOOMBERG, W. G. 1950. Fire and spruce. For. Chron. $26(2)$.

CROSSLEY, D. I. 1952. White spruce reproduction resulting from various methods of forest soil scarification. Can. Dept. of Resources and Development, Forestry Branch, Silv. Res. Leaflet No. 102.

1955a. Survival of white spruce reproduction sulting from various methods of forest soil scarification Canada Dept. of Northern Affairs and National Resources, Forestry Branch, Tech. Note No. 10.

1955b. Mechanical scarification to induce white spruce regeneration in old cut-over spruce stands. Canada Dept. of Northern Affairs and National Resources, Forestry Branch, Tech. Note No. 24.

DAY, R. J.' 1963a. Spruce seedling mortality caused by adverse summer microclimate in the Rocky Mountains. Dept. of Forestry Pub. No. 1007.

$1963 \mathrm{~b}$. The microenvironments occupied by spruce and fir regeneration in the Rocky Mountains. Dept. of Forestry Pub. No. 1037.

1965. The development and structure of the Rocky Mountain forest. Can. Dept. of Forestry, For Res. Br. Mimeo 65-A-3. $19 \mathrm{pp}$.

\footnotetext{
ging in and DUFFY, P. J. B. 1961. Regeneration after logging in the Crowsnest Forest. Can. Dept. of Forestry Pub. No. 1003.

DeGRACE, L. A. 1950. Selective logging of spruce in subalpine Alberta. Can. Dept. of Resources and Development, Forestry Branch, Silv. Res. Note No. 96.

EASLEY, L. T. and CHAIKEN, L. E. 1951. An expendable seed trap. Jour. For. 49: 652-653.

HORTON, K. W. 1956. The ecology of lodgepole pine in Alberta and its role in forest succession. Can. Dept. of Northern Affairs and National Resources, For. Br., For. Res. Div. Technical Note No. 45.

OGILVIE, R. T. 1963. Ecology of the forests in the Rocky Mountains of Alberta. Can. Dept. of Forestry, For. Res. Br. Mimeo 63-A-12.

QUAITE, J. H. 1950. Marking costs in a white spruce stand. Can. Dept. of Resources and Development, Forestry Branch, Silv. Leaflet No. 44.

SNEDECOR, G. W. and COCHRAN, W. G. 1967. Statsitical methods. Sixth Ed. The lowa State Press, Ames, lowa. $593 \mathrm{pp}$.
}

\section{Erratum}

In the August 1970 issue in the article by G. C. R. Croome, page 318, the total basal area in Table 1 for 1957 should read 90.0 and not 9.00 . 